Visa protests

\section{Who will go to Prague?}

JoHN Ziman, the British physicist, announces on p.619 his withdrawal from the Prague annual general meeting later this month of the European Physical Society (EPS). Ziman is protesting at the refusal of the Czechoslovak authorities to grant an entry visa to Czech emigré Frantisek Janouch (see Nature, 26 July, p.268), theorist and particle physicist, but it seems that Ziman will be protesting alone. He has circulated his letter to all other speakers at the Prague meeting, where he was to have given the Cecil Powell memorial lecture, but by last week neither he nor EPS had heard of any other withdrawals. The protest over the Janouch refusal seems destined to fizzle out, and EPS - says its president Godfrey Stafford - will not cancel the general council meeting on which Janouch was to sit. This says Ziman, is "scandalous and timorous",.

EPS, however, says that it would be impossible to reach agreement among the 90 -member council, many of whom are East Europeans, to cancel the meeting, and that an attempt to do so might split the delicately balanced society in two. Anyway, says Stafford, EPS has been "no less successful" this time in arranging visas than at any other meeting. Only Janouch has been refused. Visas have been arranged, for example, for the whole Israeli delegation, although Czechoslovakia has no diplomatic relations with Israel, and even - after some difficulty for a French supporter of the Charter 77 movement, outlawed in Czechoslovakia.

The main issue behind the dispute seems to be how far a "trans-bloc" scientific body such as EPS can go in pressing a case when the individual has both a scientific and a natural political interest in attending a meeting.

EPS also points out that visa refusals are not unknown in the West. At the last EPS annual general meeting at York, in Britain, an East German (Professor Bethge, of Halle) was refused a visa until the last moment, when it was too late for him to attend. At another EPS meeting at Grenoble, France refused a second East German (Professor Auth) a visa. EPS protested strongly on these occasions, but no explanations were given.

Ziman, however, says he would certainly protest at any visa refusal in any country. Moreover, he believes that Janouch is no more than outspoken about his mother country, and is not an activist. Janouch is, in fact, active in a Swedish committee supporting the Charter 77 movement, but believes such activity is "humanitarian and cultural"' only, and not political.

The president of the Czechoslovak Academy of Sciences thinks otherwise. In a reply to Ziman's circulated letter, he expresses surprise that the British physicist

\section{Particle physics}

based his protest on "one-sided information" and that he had not tried to get information from the academy about Janouch. Explaining the successes with the Israelis and others, he goes on to say "the case of Janouch is rather different. He is a Czech emigré who has been, and is, working actively against the interests of our country, and you should not be surprised at the action of our authorities."

Moreover, the letter goes on, "it would not be the first time that the activities of Janouch have threatened to split EPS". This, presumably, refers to events of 1973 , when the Czechoslovak Academy of Sciences was angling to host the 1975 EPS Congress, but was told by the then president of EPS, Professor H.B.G. Casimir of the Netherlands, that the society would be happy to accept the invitation, but that the situation of Professor Janouch could be a difficulty.

Dr Janouch had been dismissed from his job with the academy in 1970 on the grounds of "violating socialist order", thus becoming the first victim in the academy of the purge "normalizing" the situation after the Prague spring. Although offered jobs in both Denmark and Sweden, Dr Janouch could not obtain an exit visa.

As a result of Casimir's intervention, the Czechoslovak Academy of Sciences cancelled its invitation for the conference. Shortly afterwards, Dr Janouch was informed, during an interrogation by the secret police, that it would be "more reasonable of him if he applied for a passport", a suggestion reiterated by the academy authorities.

At the end of 1973, Dr Janouch was allowed to leave for Sweden, with a passport permitting him to return to Czechoslovakia within five years. In February 1975, however, he was formally deprived of his Czechoslovak citizenship, and when his appeal for reinstatement was rejected, had to apply for political asylum in Sweden. In 1979, he became a naturalized Swede.

Eighteen months ago, Janouch was elected to the general council of the EPS as one of the nine representatives of the "individual ordinary members". Ironically, had it not been for Dr Janouch, there might never have been an East European presence in EPS, and the problem of "trans-bloc" conferences might never have arisen. During the negotiations in 1967-68 which led to the foundation of the society, it was Janouch, still at that time in good political standing, who persuaded the Soviet and East European physical societies to join.

Robert Walgate and Vera Rich

\title{
Der Spiegel makes trouble
}

DER SPIEGEL, West Germany's equivalent of Time magazine, threw the West German particle physics lobby into high gear last week with a scathing article by a British "professor of atomic physics" suggesting that the latest German particle accelerator, raised by what physicists describe as the pure abuse of Parlour's article, its apparent authorship by an insider and the attention given it by publication in Der Speigel. "It's crazy", said a spokesman of the Deutsches Electronen Synchrotron at Hamburg,

\section{Sterhehilfe fiirr eine Königin}

Die teure und sinnlose Jagd nach den kleinsten Teilchen / Von Richard Parlour

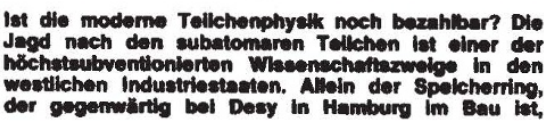

the DM6,000 million ( $£ 1,600$ million) HERA, may be about as useful as the Egyptian pyramids.

The author, Richard Parlour, until recently a $\mathrm{PhD}$ student at University College, London, has touched a raw nerve. His view exactly matches that of West German environmentalists, the Greens, who now have political power through parliamentary representation won in the last general election.

To particle physicists, HERA will be a valuable complement to LEP, the electronpositron collider being built at the European centre for nuclear physics, CERN. HERA will ultimately be colliding leptons with quarks, providing results that should dovetail with one another.

West German tempers were particularly

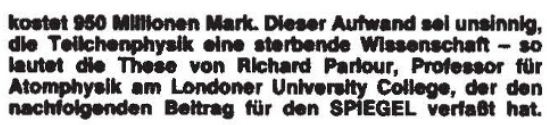

where HERA is being built. "There's not a single argument in it, it's full of errors, and it ignores the past 20 years of great advances in particle physics." Nevertheless, the article could do "enormous political damage" because of the resonance with the Greens' position and because "that's the kind of article politicians read".

If the article had been published a few months ago, when the political decision to go ahead with HERA was being made, its effect could have been more damaging. Now, however, the sensitive and active West German high-energy physics community will be taking care not to overreact. There will be some discreet damagelimitation and some letters of protest to Der Spiegel.

Robert Walgate 